\title{
The Range of Tajassos and the Reasons of its Related Primary law in Islamic Jurisprudence
}

\author{
Tourj Hemmati Farsani \\ MA in Essentials of Islamic Jurisprudence and Law, Department of Theology, \\ Islamic Azad University Isfahan (Khorasgan) Branch, Isfahan, Iran \\ Email: poya.hemmati59@yahoo.com \\ Sayyed Hossain Vaezi* \\ Corresponding Author: PhD, Assistant Professor, Department of Theology, \\ Islamic Azad University Isfahan (Khorasgan) Branch, Isfahan, Iran \\ Email: sh.vaezi@khuisf.ac.ir
}

Doi:10.5901/mjss.2016.v7n3s3p340

\section{Abstract}

One of the fundamental concepts in the field of political Fiqh (Islamic jurisprudence) is Tajassos (spying or looking for other people's affairs) in people's privacy. The aim of this study is expressing Tajassos boundaries and reasons related to its primary precept which has been developed to be used in legislative parliaments and also in familiarizing the community with this forgotten prohibition. The method of this study is analytical descriptive with the focus on library studies. The author has analyzed Tajassos in word and expression and has also clarified some of its synonyms and related words such as privacy. The study findings suggest: Based on the arguments of Islamic jurisprudence, Tajassos is prohibited in both Sunni and Emamiye Figh and the principles of its prohibition have been proven by both of them. But there are some reasons based on wisdom and Sunnah (tradition) that permit Tajassos on some important issues like protecting the Islamic government. In choosing between maintaining the Islamic system and prohibition of Tajassos and preserving the dignity of people, the rule of more important one (ahham) should be obeyed. It should be noted that ebaahe (Tajassos permit) in all these cases is based on necessities and it is similar to eating a dead person's flesh when there is not any other choice.

Keywords: Tajassos, Fiqh, Spy, Privacy

\section{Introduction}

Recognizing and exploring the legal issues and combining them with elements of time and viewing them from the perspective of time and place necessities, is essential for dynamic jurisprudence.

Discussion of Tajassos is also not a new phenomenon. Tajassos has a historical background coeval with the creation of humanity. What makes addressing the issue of Tajassos important is the concern of practicing religious duties for Muslims based on their recognition of responsibility. Time changing and needs development with the advancement of technology has necessarily developed the subject of many religious precepts in the area of practicality. This study wants to have a comparative search in the views of Ja'fari and Sunni's scholars on a new perspective through using the Qur'an and practical and spoken Sunnah (behavior) of Masooms.

Figh is considered as the most versatile, dynamic, and inventive of the Islamic disciplines, it is about the derivation of Law from the original revelatory sources in order to provide practical solutions for Muslims in this modern society (Picken, 2004).

\subsection{The meanings of the words}

\subsubsection{The literal meanings}

1. It is from the root of "javs" or "jasas" and Tajassos is masdar solasi-mazid made of bab-tafa'ol and one of its meanings is seeking.

2. If the original word is "jas" it is a medical word meaning the touching of the vessel and recognizing pulse to 
warrant a health or disease.

3. Searching for the inner affairs (Ibn Manzour, 1993).

4. Searching and looking for the information and exploring the hidden affairs with the intention of doing evil and intrigue (Johari, 1989).

5. Keep track of what you have been concealed (Ansari Ghortabi, 1944).

6. Searching information for someone else (Ansari Ghortabi, 1944).

7. Discussion and curiosity about hidden parts (awraat) (Mohaqeq, n.d.).

\subsubsection{Expressional meanings}

To explain the meaning of the term Tajassos, it has been dealt with from two angles:

1. The expressional meanings of Tajassos in the jurisprudence, narrative, and interpretive texts:

In the words of commentators, this word means the same as its literal meaning, as Tabatabai under the verse 12 of Surah Hujurat states "looking for hidden flaws and secrets of people and searching for their secrets to become aware of unfavorable covert affairs"(Tabatabai, 1973).

In the language of Fuqaha (jurists), it has been used with its literal meaning. Normally, there is not an independent discussion on the subject of Tajassos and its various aspects in the religious books; and only on the basis of the prohibition mentioned in Surah Hujurat, jurists also have ordered its prohibition.

In the traditions, it is often the literal meaning that is meant. Of course, Tajassos has often been used with the meaning of investigating and interfering with the people's secrets and sometimes with the meaning of betraying and spying on the Islamic government.

2. The expressional meanings of Tajassos in legal texts:

The meaning of this word in legal texts is different from its meaning in Islamic religious texts. In legal texts, this word and its derivatives (which is often considered spying) mean betraying the country and in these contexts it has specific meanings such as:

a. Collecting and acquisition of information and documents which can be used by a foreign country against the security of another country (Garo, n.d.).

b. Collecting secret and classified information and documents about military affairs and defensive operations or obtaining information about political or economic conditions in the country to give them to a foreign state in exchange of money or any form of reward (Validi, 980).

\subsubsection{Related words and synonyms of Tajassos}

1. Tahassos: The mentioned meanings for Tajassos are also usable for Tahassos. But other sayings have been stated in Tafsir Ibn-Kathir:

Tajassos is trying to get information to make seduction and Tahassos means getting information based on good intentions (Ibn Kathir, n.d.).

These meanings have also been accepted by Tabarsi, Neyshabouri, and Sallabi.

It seems that this saying is the superior one, because there is evidence of choosing it in the Holy Quran. About "Tahassos" there is an order In the Quran from the Prophet Jacob about Joseph (AS) which ratifies this claim. "O my sons go and inquire respecting Yusuf and his brother, and despair not of God's mercy; surely none despairs of God's mercy except the unbelieving people" (Q. 12:87).

2. Jaasus (spy): Another word which is associated with Tajassos and sometimes the concept of Tajassos is compared with this word is spy. "Spy is someone who is searching for information and investigating the affairs" (Mogri Fumi, 1984).

3. Haasus: It is another related word. "Hasus is someone who is searching for information like a spy but with good intentions, whereas the spy has evil intentions." (Ibn Manzour, 1993)

Other words such as; natas, nahas, tarassod, As'ar, tahsib, natast, ayn, and sam' are related words which are not discussed in this study.

4. Harim: Another related word with Tajassos is the word harim (privacy). In word: Arabs have mentioned two roots for the word harim:

a. Haram (shrine): It has been used in the books al-Ayn, al-Mohit, Aqrab al-Mavared, and some other books for place names. For example, haram is used for a place that should not be touched or approached (Farahidi, 1989). 
b. Haram (haraam): It means being forbidden and prohibited. According to this root of the word it means proscription and prohibition to the scope, and it is required for every individual to maintain this scope and range (Sarvari Mazandarani, 2002).

In expression: Resolution 1970 of the Council of Europe has defined privacy as " privacy issues are related to private and family life, housing and physical and mental integrity, honor, reputation and dignity of people, the refusal of making a false image of the person, non-disclosure of the irrelevant and annoying facts, nondisclosure of private images, support for non-disclosure of information that people have acquired based on trust".

According to the mentioned definitions, important and outstanding privacy cases include: personal information, people's bodies, home and private places, private communications, and people's working place.

\section{Search warrant}

In Emamiye Fiqh, people's privacy has been supported under various categories and precepts. One of these categories is the prohibition of Tajassos and inspection of secrets and private parts that people cover.

Herein based on the four rules of evidence (Quran, Sunnah, wisdom and consensus) from the perspective of Sunnah and Emamiye Fiqh, the privacy search warrant has been analyzed.

\subsection{From the perspective of verses}

Some noble verses about Tajassos have been relied on and commentators while using the words of Imams have explained and interpreted these verses and have analyzed them from different points of view and have clarified the use of them.

The verse 12 of Surah Hujurat is the first verse about Tajassos which has been much discussed and is more clear comparing the other verses about Tajassos prohibition: "O you who believe! Avoid most of suspicion, for surely suspicion in some cases is a sin, and do not spy ..."

The style of this noble verse is stating some orders in social ethics which are as follows:

1. Avoiding suspicion against the religious brothers

2. Prevention of Tajassos on people's property

3. Prevention of backbiting

The main source of Tajassos is ill thinking and suspicion about the subject of Tajassos. If we avoid evil suspicion, then we will not investigate people's secrets and their imperfections remain covered. On the assumption of suspicion, if we fulfill our ill thoughts and look for people's hidden defects, then their defects are discovered and discovering people's defects is the first sin. This first sin causes another sin called "backbiting" and this second sin leads to spreading wickedness which can be considered the third sin as the result of suspicion. Suspicion has strictly been forbidden in the Quran and the guilt of this sin is not only less than the guilt of Tajassos, but also it is far worse than that. Therefore, it is not only the act of Tajassos that is disobedience to God, but also after that backbiting, slandering, and spreading of sins are also involved.

Some commentators recognize the verse as "La Tahassasu".

As it was mentioned, scholars contradict on the meaning of "Tahassos" and "Tajassos". Abul-Futuh Razi comments on the verse 12 of Surah Hujurat: common people have read "Va la tajassasu" with j. (Razi, 1980) Abdullah Ibn-Abbas and Aburaja' Alatarody have read it "Va la tahassasu" with $\mathrm{h} / \mathrm{c}$. Another group like Akhfash has stated: The meanings of "tajassasu" and "tahassasu" are the same and there is no difference in the way of recitation. Anyway, the mooted question is what is the purpose of the prohibition of Tajassos in this noble verse? And who are its audience? And who should not be investigated?

Some have said: The precept is "exploring the privacy of others" and the emergence of the verse is in a way that 'Tajassos' is haraam/prohibited because prohibition has been stated in the verse. (Helli, 1985) In spite of the application of the verse, some commentators have considered some issues such as intending to be aware of people's secrets and defects as the requirements of Tajassos prohibition. (Tabatabai, 1973) Others according to the anti-meaning of the verse believe that believers in social relationships and evaluating others should behave based on appearances and not based on Tajassos and what is out of sight of others.

Tabatabai defines Tajassos as investigation and inquiry into the affairs that people attend to remain hidden but somebody looks for them to become aware of. (Tabatabai, 1973) Also, he assumes the reason for Tajassos prohibition to be the very same reason for backbiting prohibition. The very same reason that has been stated for the prohibition of 
backbiting in the verse "would any of you like to eat the flesh of his brother" has been declared in the verse 11 of Surah Hujurat as the reason for Tajassos prohibition because the only difference between Tajassos and backbiting is that backbiting is the revealing of people's defect to others -whether we have seen it ourselves or heard it from someone else- and Tajassos is finding information about people's defects by any means (it can be ears, eyes, or any of today communication means). But searching for people's defects is common in both of them and therefore it is not unlikely that the sentence "would any of you like to eat the flesh of his brother" can be extended to both of the sentences "la tajassasu" and "la yaqtab bazokom baaza" Based on this interpretation it can be said that someone who searches people's hidden affairs is eating the flesh of his dead brother like the backbiter; and this severity in prohibition of backbiting also includes Tajassos and this is a very considerable matter(Tabatabai, 1973).

Tabarsi has interpreted the prohibition of Tajassos as referring to people's defects and he explains the verse as "do not look for Muslims' defects and do not desire to disclose whatever their owners like it to remain covered"(Tabarsi, 1985).

Nasr Ibn-Muhammad stated: "La tajassasu" means do not discuss about the defects of your religious brothers; IbnAbi Hatim (d. 1419/1998) also follows Ibn-Abbas in defining Tajassos as the discussing about Muslims' defects and disclosing whatever they cover and getting information about their secrets (Samarqandi, n.d.).

Qortabi has said: Muslims have been prohibited from suspicion that leads to Tajassos and looking for a Muslim's defects.

In Kashf al-Asrar, Taftazani has stated that: Tajassos is prying into a hidden thing to make it appear. Allah says: Be satisfied (about your faithful brother) with what is unhidden and beware of what is not clear and leave it unknown. (Taftazani, 1958) Albaqvi for the interpretation of the verse has said that the prohibition of Tajassos refers to everything that people cover and they do not like it to be apparent; and trying to discover it is also forbidden, and no one has the right to search it(Al-Baqvi, n.d.).

In explaining the verse, Qortabi believes that we should consider people's external behavior as the criterion for our understanding and should not search for people's defects. No one should look for their religious brother's defect because God has covered it (Ansari Ghortabi, 1944).

Another significant verse which has a special place in this debate is the verse 19 of Surah Nur:

"Truly those who like that scandal should circulate respecting those who believe, they shall have a grievous chastisement". Although this verse does not obviously asserts Tajassos prohibition, it prohibits spreading wickedness which is the result of surveillance and inspection; and if we believe in the prohibition of introduction to haraam it can be said that from this verse the prohibition of spying on Muslims' defects can also be understood. According to this reasoning, if spying and Tajassos is not a preliminary step for spreading scandal then based on this verse it cannot be banned. For example, spying is not the case of this verse when the Islamic government has to spy on people for great expedience and for preventing the spread of wickedness.

Another verse about spying that can be referred is the verse 189 of Surah Baqarah:

"It is not righteousness that you should enter the houses at their backs, but righteousness is this that one should guard against evil". (Q. 2:189)

Although in this holy verse Tajassos has not explicitly forbidden as it has in the first verse, with a little consideration and based on the verse it can surely be proved that the spying is reprehensible and abominable; for God Almighty in this holy verse has denounced one of the ways that leads to the spread of wickedness and disclosure of people's imperfections. And that is the unusual way of entering into people's houses. Therefore, based on the reasons in this verse, it can be perceived that Tajassos and spying is a reprehensible and evil act.

Other verses that can be relied on for getting the primary precept of prohibition in Tajassos and spying are the verses 27 and 28 of Surah Nur: "O you who believe, do not enter houses other than your own houses until you have asked permission and saluted their inmates; this is better for you, that you may be mindful". (Q. 24:27-28)

"But if you do not find any one therein, then do not enter them until permission is given to you; and if it is said to you: go back, then go back; this is purer for you; and Allah is cognizant of what you do".

Also, these two verses do not explicitly prohibit Tajassos and spying but one of the means of spying that is entering into people's houses without their permission has been explicitly prohibited. And as it has been proved in the principles of Fiqh, 'nahy' refers to 'tahrim' (prohibition) and therefore based on the prohibition of entering into people's houses without their permission, the prohibition of Tajassos and spying on people's houses and behaviors can be ordered.

Another holy verse that some Fuqaha (jurists) have understood the primary precept of spying and Tajassos from is the verse 94 of Surah Nisa: "O you who believe, when you go to war in Allah's way, make investigation, and do not say to anyone who offers you peace: you are not a believer. Do you seek goods of this world's life? But with Allah there are abundant gains; you too were such before, then Allah conferred a benefit on you; therefore make investigation; surely 
Allah is aware of what you do". (Q. 4: 94) Based on the pro-meaning of the verse, the prohibition of spying on people can be concluded; because this verse forbids investigation on people and it implies that the believers should be contented and satisfied with apparent things and do not search for internal aspects of people's actions and words.

As a result, according to these verses, spying on people's (whether believers or atheists) privacy is absolutely forbidden and breaching it requires specific reason.

\subsection{In the views of traditions:}

One of the reasons of precepts in Islamic religious jurisprudence is traditions (ahadith). Of course, the way of using these narratives is different between Shiites and other sects. Shiites only accept the Prophet and the Ahlul Bayt's (as) narratives with specific criteria but the Sunni accept the Companions (sahabeh) and Followers' (tabein) narrations as well. Investigation from the perspective of the Prophet (peace be upon him and his progeny)

1. Under the explanation of verse 12 of Surah Hujurat, Qortabi has restated the saying of the Prophet (pbuh): "Beware of the suspicion to others, because the word that is said based on suspicion and mistrust is the worst lie. Do not investigate people's overt or covert affairs (whether with good or bad intention), and do not be curious and do not disclose each other's secrets. And also do not be jealous of each other and do not backbite; be the servants of God and behave each other brotherly". (Ibn Hanbal, 1993) Expressing this narration is a social educational act which is directly related to people's dignity. The prohibition ordered by the Prophet is related to "la tahassasu va la tajassasu". We have been prohibited of Tajassos even out of good intention because spying on people's privacy leads to disclosure of defects and disgrace.

2. Majlesi has stated a long narrative about the believers' characteristics from the Prophet (peace be upon him and his progeny): " ... do not enter into affairs that is not their business... and do not disclose the people's secrets ... it is a must for every Muslim and believer to try to accomplish their science and faith in every single day of their life". (Majlesi, 1981) In this expression, the Prophet has considered not investigating people's affairs as the condition of the perfection of faith; and has stated that anyone who looks for people's affairs has not a complete faith. For, those people who are engaged in people's imperfections have remained unaware of themselves and their performance.

3. While expressing ethical points to Ali (AS), the Messenger of Allah (peace be upon him and his progeny) stated: "Eight groups should not blame anyone other than themselves if they are disrespected ... those who want to be aware of people's secrets"; and beside the prohibition of Tajassos, He puts the blame of the consequences of Tajassos on the investigator and as it is clear in His narration, the least reaction of Tajassos is reproaching and reprimand. And people with the characteristic of Tajassos have not respect in the community and people allow themselves to insult them (Majlesi, 1981).

4. In Savab al-A'mal va Eqab al-A'maal, Saduq has stated a long narrative that a part of it is about prohibition. The Prophet forbade anyone to seek information from their neighbor's house and said: "Whoever intentionally looks at their Muslim brother's private parts and genitals rather than their own spouse, the Almighty God throws them into hell with the hypocrites; because those people in the world were constantly looking for people's imperfections".(Ibn Babuyeh, 1985) The Prophet has also promised these people the same punishment as of hypocrites; and since the punishment has been promised for major sins, therefore, Tajassos is certainly a major sin. According to the words of most fundamentalists, the Prophet's (PBUH) use of 'nahy', which He forbids investigating others, confirms its prohibition.

5. Saduq has narrated from Ibn-Abbas that the Prophet (peace be upon him and his progeny) in the last sermon he gave in Medina, said: "Anyone who takes steps in searching for their brother's defects, they are stepping into hell; and God will reveal their imperfections to the public. Herein, Allah (Almighty) challenges the spies and has promised to disgrace them if they defame people". According to the intensity of this promise, the importance of the issue can be realized (Ibn Babuyeh, 1985).

\subsubsection{Tajassos from infallible Imams' (PBUH) views:}

One of the responsibilities of the community officials is protecting people's lives and dignity. Like the Holy Prophet (peace be upon him and his progeny), the infallible Imams (peace be upon them) are also trying to build a strong fortress and give people comfort and safety. They (PBUT) have beautifully explained the issue in the light of the Quran and luminous words of the Prophet (peace be upon him and his progeny). There are a lot of narratives related to the prohibition of 
Tajassos, and permission for punishing the investigator. In addition, in some narrations, it is permissible to harm or even kill the spy; even through referring to these narratives, the prohibition of Tajassos can be proved.

These narratives are so numerous and important that in volume 6 of Bahar al-Envar, Majlessi has opened a chapter entitled "Tattabeo fi al-dour" (In the role of looking) and Tattabeo oyub al-nase efshaeha" (Investigating people's defects is revealing) and has gathered the related narratives. Also, Koleni has opened a chapter entitled "Man talab atrate al-momenine ouratehem" (In search of believers' defects and privacy) in volume two of Osule Kafi. Sheikh Horr Ameli, in volume 12 of Vasael al-Shia'h, has opened the chapter of "Tahrim ehsae atarat al-momen" (The prohibition of believers' defects). Also, in Moshtarak al-Vasayel, Mohaqeq Nuri has allocated a chapter dealing with the way of punishing those who nose into people's privacy.

In conclusion, based on the traditions on the issue of Tajassos prohibition, no one has the right to nose into people's privacy and search for their secrets and if it happens, the person who has been spied has the right to harm and punish the intruder.

As a sample, some of these traditions are mentioned:

1. In a letter to Malek Ashtar, Imam Ali says: "and you should avoid and be the most hostile to someone who insists on revealing people's imperfections; ... so do not be curious of hidden people's defects and ...." (Nahj al-Balaqah, n.d.) In the letter, Imam (A) prohibits Malik of curiosity about the people's defects and even forbids him from making friendship with those who investigate and reveal people's imperfections; and based on the scholars principles "Al-nahy yadal ala hormat" the word nahy implies prohibition.

2. Imam Sadeq has restated from the Messenger of Allah (peace be upon him and his progeny) that: "O you who have accepted Islam just by your mouth and faith has not entered into your hearts! Do not speak ill of Muslims and do not search for their defects because everyone who searches for people's defects God will search for their faults and whoever God do this to them God will defame them even if they are in their houses ". (Koleini Raazi, n.d.) This narration refers to the prohibition of Tajassos and explicitly mentions the prohibition of investigating people's privacy. The word nahy implies prohibition so spying on Muslims whether believer or nonbeliever is absolutely forbidden.

3. In another hadith, looking at believers' private parts have been banned; Imam Ali (as) has been asked: "Can a believer look at believer's private parts? He said: Yes. I asked: Do you mean the genitals? He said: Not as you imagined, but I mean revealing their secrets" (Majlesi, 1981).

Looking at people's genitals is prohibited and requires atonement. As people cover their private parts by wearing clothes this means that others do not have the right to look at their private parts; doing a sin in secret also means the same. Therefore, no one has the right to spy on the privacy of others to reveal their sins and to cause people's defamation because they have covered their sins like their genitals. Therefore, based on these traditions, spying on people's secrets and their faults are forbidden. Of course, from this narrative, it becomes clear that someone who is notorious for debauchery is like the person who appears nude in the society and they cause defamation for themselves.

This noble hadith prohibits revealing the secrets of people and retelling the things that people do not want anyone to know them. Whether the person has revealed the secrets that becomes aware of through investigation or the secrets that a believer themselves have entrusted them with. Consequently, spying on people's secrets which has been considered the same as looking at people's genitals and also disclosing secrets are forbidden based on this noble narrative.

4. Imam Baqir has said: "Searching for believers' imperfections is forbidden for the believers". He has also stated: "Whoever does spying on believers' houses, damaging their eyes is permissible for the owner of the house under spying (and there is no blame on the owner)"(Ibn Babuyeh, 1985).

5. Imam Sadeq has narrated from the Messenger of Allah (peace be upon him and his progeny) who said: "Three things is a sign of ignorance: a) Changing friends (it means that the person leaves their friend to make friendship with someone else, because it is rational to increase friends and not to lose friends) b) separation and withdrawal (from friends) without revealing the cause of it (because if the reason is mentioned they may fix the problem, or maybe this person has mistakenly suspected or doubted and expressing the cause can help solving the problem) c) investigation of irrational and unnecessary things". (Majlesi, 1981) This narrative is a guiding (not an obligation) order because changing friends, separation without declaration, and searching for useless things are not banned.

6. Imam Sadiq (AS) said: "There are three groups that are suffering in Doomsday .... Those who listen to people while they are unsatisfied and unhappy". (Arousi Joozi, 1994) Promising the punishment certainly implies prohibition. Fuqaha have used this narrative for prohibition of three things; because promising and intimidation 
in this hadith refers to prohibition. (Montazeri, 1994) From these traditions, it is implied that any information that causes a believer's humiliation is the justification for spreading wickedness although the teller has not such an intention and such an act is unlawful and prohibited.

As a result, according to the traditions, the prohibition of Tajassos is absolutely achieved; whether it is out of good or bad intentions. The exceptions with constant evidence will also be mentioned in due course.

\subsubsection{Tajassos in the view of the Prophet's Companions}

There are a lot of traditions about the prohibition of Tajassos in Sunni sources. For example, in Sonan Beihaqi there is a chapter entitled (prohibition of Tajassos) and many traditions with the theme of Emamiyeh traditions have been narrated. (Koleini Raazi, n.d.) For instance, it has been quoted from the Prophet (peace be upon him and his progeny) in Sahih by Moslem, Mosnad by Ahmad Ibn-Hanbal, Mosnad by Tiyalisi, and al-Dovar al-Mansuor: "...do not search for hidden and obvious affairs of people and do not be curious and do not disclose each other's secrets..."(Ibn Hanbal, 1993) In addition to the mentioned traditions, there are some narrations about the Companions' behavior which are referred to in Shiite Fiqh. Some of these narrations have been mentioned here.

1. Telling a story about Tajassos which happened for Salmaan Farsi, a well-respected and great companion, shows that the Companions have profusely struggled to obey the Quran's and the Prophet's (peace be upon him and his progeny) order. The behavior of each one of them as a Mujtahid (Sunnis know the Companions as Mujtahid in understanding and practicing the laws) is authorized and binding.

Salmaan Farsi was the governor of the second Caliph (Omar) in Madaen. He received a letter from the Caliph to investigate and report the actions and deeds of Hazifat Ibn-Yaman who was the governor of Madaen before Salmaan. In response to the Caliph, Salmaan Farsi wrote: "Your letter reached me to ... inform you of good and evil of Hazifat Ibn-Yaman. Allah has forbidden us from this action. In the Holy Quran, Allah has said: "O you who have believed, avoid a lot of suspicion ... and do not search". (Majlesi, 1981) This story shows that Salmaan Farsi prioritizes his understanding of the Quran to understanding of the Caliph and mentions this point in his response.

2. From the Messenger of Allah (peace be upon him and his progeny), Abu-Huraireh narrates that "Having good opinion of people's conduct and behavior is a sign of worshiping God." (Ibn Hanbal, 1993) This narrative urges the believers that if they have a good opinion of other believers and do not suspect them, this act is considered as your worship; therefore, this holy narration is for prevention of suspicion which is the introduction to Tajassos.

3. In Mosnad, Ibn-Hanbal has stated that the Messenger of Allah (peace be upon him and his progeny) said: "I advise you to avoid suspicion of your faithful brother because the suspicion is the biggest lie." And on the following he declares that suspicion in traditions certainly means evil thinking not good thinking because thinking positively is praiseworthy. Therefore, if you suspect a believer, do not react and do not start spying on them and do not do action that would insult them. And this suspicion is subject to divine injunction as Allah said: "Do not spy" because suspicion is an internal affair and it is out of the human's control but Tajassos is optional (Ibn Hanbal, 1993).

4. In long words from the Prophet, Abu-Hurairah narrates that avoid bad suspicion because it is the biggest lie and do not search. (Ibn Hanbal, 1993) As it was mentioned above, Tajassos is searching for the people's defects. But the prohibition in this tradition of the Prophet includes the search for defects and whatever rather than defects; because if somebody searches for believers' perfections, they will inadvertently access to some of their imperfections.

5. Ahmad Ibn-Hanbal explains Ibn Mas'ud's performance encountering Tajassos in this quotation: the narrator says: I was with Abdullah Ibn-Mas'ud and I saw a man came while the wine was dripping from his beard. I told Ibn-Mas'ud is he such and such the person in this condition. As he cannot see this scene, Abdullah IbnMas'ud said: We have been prohibited from spying on others, but if it became apparent then it can be invoked. (Ibn Hanbal, 1993) According to this narrative on the prohibition of Tajassos and considering the word of the Prophet who said: "Do not search for each other's hidden and secret affairs", the strength of this ban is obvious; because the person who openly does something is firstly notorious for debauchery. Secondly, looking at them is not considered as Tajassos.

The word of Ibn-Mas'ud can refer to the rule of "Esalat al- seha" (righteousness originality). For example, it is water not wine that is dripping from the person's hair and beard. Although he is accused of debauchery, but we also do not investigate whether it is water or wine that is dripping from his beard. This can be considered 
as a sign of the Companions' understanding of the greatness in prohibition of Tajassos. Of course, when he says if it became apparent then it can be invoked refers to Tajassos permit about the person who is notorious for debauchery.

Consequently, it can be achieved from the narrations about the Companions' words and actions that they were concerned about preserving the dignity of Muslims and they considered Tajassos as a prohibited act and they avoided it.

\subsubsection{From the perspective of wisdom:}

Human's wisdom has denounced anarchy, social corruption, insecurity, and spreading wickedness and it fights for removing the disruption from people's lives. One of the things that cause insecurity and anarchy in the society is searching for people's secrets and privacy. Referring to common sense, Tajassos is an indecent act and every wise person accepts that Tajassos causes moral and psychological insecurity and ultimately it leads to scandal and defamation.

On claiming Tajassos prohibition, Sheikh Ansari states rational reason as well as traditional reason on the prohibition of Tajassos and the fact that wisdom bans publicizing people's defects. He declares: "There is no hesitation on wisdom and traditions that publicizing and spreading of what causes the believers' humiliation and loss of their social dignity is forbidden. The wise unanimously believe that searching for people's affairs which they try to hide leads to the loss of their social status." (Mehrizi, 1999)

In addition to the scholars' unanimity on the prohibition of Tajassos, Rakan al-Damqi claims that rational reasons also prove that no one has the right to search for the Muslims' privacy. In the following he also restates from Ghazali that referring to rational reasons proves Tajassos prohibition (Al-Damqi, 1985).

\subsubsection{From the perspective of consensus:}

According to the verses and traditions mentioned earlier, also views of the Shiite and Sunni scholars, the first principle is Tajassos prohibition and this prohibition is also consensus that is all Muslims consider it forbidden (Ansari, 2008).

Shia scholars have a consensus on the prohibition of Tajassos. Fazel Javad in his book acknowledges this fact. Of course, it is a consensus document with no authority. (Kazemi, n.d.) Some have gone further and believe in Muslims' consensus on Tajassos prohibition, and they consider the prohibition of Tajassos as axioms of religion (Najafi, 1983).

Mianji also says: Tajassos prohibition is unanimous, that is all Muslims consider it banned (Ahmadi Mianji, 2005).

In Tafsire al-Kashef, it has also been documented on Tajassos prohibition based on the Qur'an, Sunnah, consensus, and wisdom; and it has been stated that scholars have consensus that if someone while spying is hurt in the eyes even killing them is allowed (Mughniyeh, 1970).

Scholars unanimously agree that if someone wants to know the secrets of the Muslims that are forbidden for them, they should be banned; because this banning is protecting people's credit. But if they insisted on this investigation they should be sent away by throwing stones or hitting with sticks. In this case, no criminal damage is in the liability of the doer and being damaged while investigating is a waste (Najafi, 1983).

In the book Dayerat al-Ma'aaref, Aameli has also claimed the consensus on the prohibition of Tajassos (Damush Ameli, 2002).

In Ehya al-Olum, Ghazali has also claimed the consensus on the prohibition of Tajassos (Ghazali, n.d.).

Consensus is a kind of Lobbi reasons and in case of uncertainty the certain part would suffice. For example, if we doubt whether the prohibition of Tajassos refers to all human beings or it is just for Muslims, the prohibition of searching for only Muslims should be assumed. For instance, if the main basis for the prohibition of Tajassos is the consensus and the person doubts whether Tajassos out of good intentions is also forbidden or not, then they should consider the prohibition only for Tajassos out of evil intentions. Of course with the evidence of the consensus, there is not any place for this discussion and it would be useless.

\section{Sireh al-Mutisharri'al "The way based on religion"}

Sireh is people or a particular group's habit of doing something. It has different categories, including: Companions Sireh, Sireh of the wise, practical Sireh of the people of Medinah, Sireh al-Mutisharri'a and.... Regarding the issue at hand, if there is no evidence other than Sireh al-Mutisharri'a in the verses and traditions and the evidence is the Muslims' consensus and actions on an issue, , only in this way, Sireh al-Mutisharri'a becomes the referring source for Fuqaha. 
Emamiyeh (Shiite Muslims) do not consider it enough but the Sunnis are independently has invoked its authority.

On the issue of Tajassos, there is the practical unanimity of the Prophet (peace be upon him and his progeny) and the Imams and the prohibition of Tajassos in his Companions' thought is a certain and undoubted matter.

\section{Cases of Tajassos permit:}

As it was mentioned, Tajassos of Muslims' secrets and looking for their flaws is forbidden and Islamic scholars have also expressed its prohibition.

Question: Is Tajassos forbidden in all kinds or does it have exceptions like some of the other prohibitions?

Answer: The above question is cleared by saying these two things:

1. In most narratives about Tajassos, the two factors of faith and fraternities have been focused on and their involvement in the prohibition of Tajassos has been referred to. Therefore, those who are against Islam and faith and spread seditions among Muslims are exception to this rule and Tajassos about them is permissible.

2. According to the more and most important rule, in conflicting two important matters, the more important matter is always preferred to the less important one. Therefore, where ever there are two matters of Tajassos prohibition and maintaining the Islamic system or preventing anarchy, maintaining the Islamic system which is the most important issue is preferred to the other issues. According to this rule, Tajassos is allowed for clarifying the truth, discovering the tyranny, identifying the hypocrites, knowing the way of staff dealing with clients, admission and hiring of government employees and etc.

\section{Conclusion}

Islam has harshly fought against the actions which poison the society and defame the people and on the other hand it has praised the actions which prevent disturbance and keep the Islamic society healthy and keep people's respect. This is confirmed by examining the evidence of two matters that the primary precept for Tajassos is prohibition and nobody has the right to search for people's privacy. And the intensity of this prohibition is obvious in the verses, traditions, practical way of religion, and rational behavior of Muslims that it has promised severe punishment for those who search for people's privacy. is a first principle in respect of surveillance and privacy of others who do not have the right to investigate the reasons of verses and traditions, theologians practices, in addition to being rational practice of intensive construction is Muslim, those who kill the other hidden surveillance has promised punishment.

If commands expressed in the verses 11 and 12 of Surah Hujurat about the prohibition of mockery, fault finding, bad nickname calling, bad suspicion, Tajassos, and backbiting is fully implemented in a community, the honor of individuals is guaranteed. No one is allowed to deride others, to find fault in somebody else, to break people's personalities by expressing ugly epithets; nobody is even permitted to suspect others or search for the people's privacy or reveal their hidden defects.

This prohibition and its exceptions are in common among Madhahib (sects) and the Shiite and Sunni have the same claim and reasons for its prohibition and exceptions. However, there are slight differences in the method of spying on their comments.

So the primary principle in respect of Tajassos is prohibition, even if the intention is good in searching for other people's affairs; and the Shiite and Sunni clerics have reached a consensus in prohibition of Tajassos, and expulsion and persecution of the spy, non-liability for crimes against the spy.

Therefore, searching for the people's secrets is prohibited and this prohibition is not binding. In cases that personal or social interests demand investigation, and these interests are more important than the honor and the secrets of the people, Tajassos is permissible and even required.

\section{References}

Abolfotoh Razi, Jamal o'din Hossein bin Ali, Rouz Al- Janan Va Rooh Al- Janan [Razi Interpretation] (Qom: Daar Al- Hadith Publication, 2003).

Ahmadi Mianji, Ali, the Necessity of Information Ministry and Islamic Sovereignty (Tehran: Dadgostar Publication, 2005).

Al-Baqvi, Hossein Ibn Masoud, Malem-Ol Tanzeil Fe-L Tafsir Quran (Beirut: Dar Ehia Al- Totas Al- Arabi Publication, N.d.).

Al-Bayhaqi, Abi Bakr, Al-Sunan Al-Kubra (Heidar Abad: Dayerat Al-Maaref Al- Osmania, 1936).

Al-Damqi, Mohammad Rakan, Al- Tajasos Va Ahkama Fi Shariat Al- Eslmia [Tajasos and Its Rules in Islam S Religion] (Egypt: Dar ALSalaam Publication, 1985).

Ansari Ghortabi, Mohammad Ibn Ahamad, Al- Jaame Leahkam Al-Qur'an [an Unabridged Book of Qur'an's Principles and Rules] 
(Tehran: Nase Khosroo Publication, 1944).

Ansari, Mohammad Ali, Al- Mosuat Al- Faqiha Al- Masira, (Majma Al- Fekr Al Eslamia, 2008).

Arousi Joozi, Abdolali bin Jome'e, Tafsir Noor Al-Saqalein [the Interpretation of Noor Al- Saqalein] (Qom: Al- Matbaat Al- Elmia Publication, 1994).

Damush Ameli, Ali, Information and Security Encyclopedia in Islamic Works and Exts (Tehran: Imam Hossein University Publication, 2002).

Farahidi, Khalil bin Ahmad, Al- Ein (Qom: Hejrat Publication, 1989).

Feiz Kashani, Mohammad bin Mohsen, Al-Vafi (Qom: Maktaba Amiralmomenin Publication, 1986).

Garo, Rene, Theoretical and Practical Studies on Criminal Law, Translated by Ziaodin Neghabat (Tehran: Ibn Sina Publication, N.d.).

Ghazali, Abu Hamed Mohammad, Ehia Olum Al- Din [Revitalizing the Rules of the Religion] (Beirut: Dar Al- Maarefah, N.d.).

Hassas, Ahmad bin Ali, Ahkam Al-Quran (Beirut: Dar Ehia Al- Totas Al- Arabi Publication, 1984).

Helli, Hassan bin yousof, Mabadi Al-Vosool Ela Elm Al- Osool [the Ways of Reaching to Principle and Rules Science] (Beirut: Daar AlAzva Publication, 1985).

Hor Al- Ameli, Mohammd bin Hassan, Vasael Al- Shia Ela Tahsil Masael Al-Sharia [the Shia'S Rules and Principles to Reach Religion'S Issues] (Qom: Moassese Al- Abeit, 1988).

Ibn Abi Hatim, Abd-ur-Rahman Ibn Mohammad, Tafsir-Ul-Quran Al-Azim (Saudi Arabia: Maktabah nizar mustafa al-baz, 1999).

Ibn Babuyeh, Mohammad Ibn Ali, Man La Yahzar Al- Faqih (Qom: Islamic Publication, related to the teachers` community, 1985).

Savab Al-A'mal Va Aqab Al-A'mal, Translated by Akbar Ghafari (Tehran: Sadoogh Publication, 1979).

Ibn Kathir, Esmaeil Ibn Omar, Tafsir Al-Qur'an Al-'Azim (Beirut: Daar Al- Maarefah, N.d.).

Ibn Hanbal, Ahmad bin Muhammad, Al-Musnad (Beirut: Daar al Fikr, 1993).

Ibn Manzour, Muhammed bin Makram, Lisan Al-'Arab (Bayrut: Dar al-Fikr, 1993).

Johari, Esmaeil bin Hamad, Al- Sehah (Beirut: DAAR Al- Elm Lelmalaeen, 1989).

Kazemi, Javad, Masalek Al-Afham Ela Ayat Al- Ahkam [the Methods of Understanding Qur'an's Verse of Rules] (Beirut: Dar Ehia AlTotas Al- Arabi Publication, N.d.).

Koleini Raazi, Abi Jafar Mohammad bin Yaghoub bin Eshagh, Osoole Kafi [Unabridge Principles] (Tehran: Dar Al-Kotob Al- Islamia, N.d.).

Majlesi, Mohammad Bagher, Behar Al- Anvar (Beirut: Dar Ehia Al- Totas Al- Arabi Publication, 1981).

Mehrizi, Mehdi, 'Religious Government and Privacy', Journal of Islamic Sovereignty (1999).

Mohaqeq, Mohammad Bagher, an Encyclopedia of Qur'an (Tehran: Besat Publication, N.d.).

Montazeri, Hossein Ali, Derasat Fi Al- Makaseb Al-Mahrame (Qom: Tafakkor Publication, 1994).

Mogri Fumi, Ahmad bin Mohammad, Al-Mesbah Al-Moneir (Dar Al- Hejra Publication, 1984).

Mughniyeh, Mohammad Javad, Tafsir Al-Kashef [the Interpretation of "Al- Kashef"] (Beirut: Dar Al- Elm, 1970).

Najafi, Mohammad Hassan, Valuable Speech on the Interpretation of the Book of "Sharaye Al- Islam" [Javaher Al-Kalam Fi Sharh Gharaye Al- Islam] (Beirut: Dar Ehia Al- Totas Al- Arabi Publication, 1983).

Picken, Gavin, 'Figh Today: Muslim as Minorities. Journal of Qur'anic Studies', 6:1 (2004), pp. 149-53.

Quran, Holy, Translated by Mh Shakir (Qom: Ansarian Publication, 2002).

Razi, Sayyid. Nahj-Al-Balagha (Beirut, 1980).

Samarqandi, Naser bin Mohammad bin Ahmad, Bahr Al-Oloom [the Sea of Knowledge] (Beirut: Daar Al- Marefa, N.d.).

Shartuni, Saeed Khori, Aqrab Al- Mavared (Qom: Manshurat Maktaba Ayatollah Marashi Najafi, 1982).

Sobhi, Saleh, Nahj Al-Balagha Interpretation (Qom: Daar- Al Hejre, N.d.).

Sarvari Mazandarani, Mohammad Saleh, Al-Kafi Interpretaion (Tehran: Al- Maktabat Al- Eslamia, 2002).

Tabarsi, Fazl bin Hassan, Mjma Al- Bayan Fi Tafsir Al-Quran [the Obvious Reason in Qur'an's Interpretation] (Qom: Esmaeelian Publication, 1985).

Tabatabai, Mohammad Hossein, Al- Mizan Fi Tafsir Al-Qur’an (Beirut: Moassese Al- Elmi Lelmatbuaat, 1973).

Taftazani, Sa'ad Masoud, Kashf Al- Asrar Va Oddat Al- Abrar (Tehran: Tehran University Publication 1958).

Tialisi, Solaiman. Mosnad Abi Dawood Tialisi, (Beirut: Dar Al-Kotob Al-Elmia, 2004).

Validi, Mohammad Saleh, Specific Criminal Law (Amirkabir Pblication: Tehran, 980). 